\title{
IFN- $\gamma$-Driven Intratumoral Microenvironment Exhibits Superior Prognostic Effect Compared with an IFN- $\alpha$-Driven Microenvironment in Patients with Colon Carcinoma
}

\author{
Sandra Grenz, ${ }^{*}$ Elisabeth Naschberger, ${ }^{*}$ Susanne Merkel, ${ }^{\dagger}$ Nathalie Britzen-Laurent, ${ }^{*}$ Ute Schaal, * Andreas Konrad, * \\ Michael Aigner, ${ }^{\ddagger}$ Tilman T. Rau, $^{\S}$ Arndt Hartmann, ${ }^{\S}$ Roland S. Croner, ${ }^{\dagger}$ Werner Hohenberger, ${ }^{\dagger}$ and Michael Stürzl ${ }^{*}$
}

From the Division of Molecular and Experimental Surgery, ${ }^{*}$ Department of Surgery, ${ }^{\dagger}$ the Departments of Internal Medicine 5 and Haematology/Oncology, ${ }^{\ddagger}$ and the Institute of Pathology, ${ }^{\S}$ University Medical Center Erlangen, Erlangen, Germany

\author{
Accepted for publication \\ August 26, 2013 \\ Address correspondence to \\ Michael Stürzl, Prof. Dr. rer \\ nat., Division of Molecular and \\ Experimental Surgery, Depart- \\ ment of Surgery, University \\ Medical Center Erlangen, \\ Schwabachanlage 10,91054 \\ Erlangen, Germany. E-mail: \\ michael.stuerzl@uk-erlangen. \\ de.
}

\begin{abstract}
Interferon (IFN) $-\alpha$ and IFN- $\gamma$ are cytokines with potent immunomodulating and anti-tumor activities. It is unknown which of the two IFNs may be more potent in the regulation of an anti-tumorigenic response in colorectal carcinoma or whether both cytokines cooperate. We, therefore, established human myxovirus resistance protein $A$ and human guanylate-binding protein-1 as markers for the differential detection of IFN- $\alpha$ - and IFN- $\gamma$-driven tumor micromilieus, respectively. In vitro studies with different cultures of tumor cells from colorectal carcinoma and stroma cells showed that the expression of myxovirus resistance protein A was exclusively induced by IFN- $\alpha$, whereas guanylate-binding protein-1 was strongly induced by IFN- $\gamma$ and only weakly by IFN- $\alpha$. This expression pattern was used to distinguish cell activation caused by the two cytokines in a clinical cohort of patients with colon carcinoma ( $n=$ 378). Patients with primary tumors expressing only guanylate-binding protein-1 exhibited the highest cancer-specific 5 -year survival $(94.0 \%, P=0.006)$ compared with those expressing both factors $(90.3 \%$, $P=0.006)$, myxovirus resistance protein A alone $(83.5 \%, P=0.096)$, or none $(72.8 \%)$. Our study describes a successful proof-of-principle approach that complex cytokine interaction networks can be dissected in human tissues and demonstrates that an IFN- $\gamma$-driven tumor microenvironment exhibits a superior prognostic effect compared with an IFN- $\alpha$-driven tumor microenvironment in colon carcinoma. (Am J Pathol 2013, 183: 1897-1909; http://dx.doi.org/10.1016/j.ajpath.2013.08.025)
\end{abstract}

Colorectal cancer (CRC) is the third most common cancer in men and the second most frequent cancer in women worldwide, showing a wide geographical variation with higher rates in industrialized countries. ${ }^{1}$ Most CRCs are sporadic carcinomas. ${ }^{2}$ Only a few CRC cases are of hereditary origin or arise in association with inflammatory bowel disease. 2,3

At the cell biological level, CRC is considered as an interaction network of epithelial-derived tumor cells and a stromal component with endothelial cells, fibroblasts, and infiltrating immune cells. The intercellular interactions are mediated by cytokines, growth factors, and chemokines constituting the so-called tumor microenvironment. The tumor microenvironment influences tumor cell growth, differentiation, invasion, and survival, but is also involved in the regulation of important stromal reactions, including angiogenesis and inflammation. Angiogenesis plays an essential role in tumor progression and in invasion and metastasis. ${ }^{5}$ Chronic inflammation contributes to tumor initiation and progression,

\footnotetext{
Supported by the German Cancer Aid grant 109510 (E.N. and M.S.), the German Research Foundation grants DFG: KFO257 (sub-project 4), SFB 796 (sub-project B9), and GK1071 (sub-project A2) (M.S.), the German Federal Ministry of Education and Research grants 01ES0807 and 01ES1001 (M.S. and R.S.C.), and the Interdisciplinary Center for Clinical Research of the University Medical Center Erlangen (E.N., R.S.C, and M.S.).
} 
whereas acute inflammation is considered to counteract tumor progression and tumor recurrence. ${ }^{6,7}$ In CRC, acute inflammation is characterized by the release of several chemokines and different inflammatory cytokines, such as interferon (IFN)- $\alpha$, IFN- $\beta$, and IFN- $\gamma$, resulting in a T-helper type 1 (Th1) immune reaction. ${ }^{7,8}$ A Th1-dominated tumor micromilieu is strongly associated with a positive prognosis in CRC..$^{9-11}$

Interferons are inducible cytokines with antiviral and cell growth regulatory effects as well as anti-tumor activities and emerge as central coordinators of the tumor-immune system interactions. ${ }^{12}$ The type II interferon, IFN- $\gamma$, targets the maturation, differentiation, and activation of immune cells and leads to an increased expression of major histocompatibility complex (MHC) class I and MHC class II molecules. $^{13,14}$ IFN- $\gamma$ is the hallmark of the Th1 immune response and affects the cancer immunoediting process. ${ }^{15,16}$ In addition, it displays anti-proliferative, anti-angiogenic, and pro-apoptotic effects by directly affecting both tumor cells and cells of the desmoplastic stroma, including endothelial cells. ${ }^{16,17}$

IFN- $\alpha$ is a type I interferon and exerts its immunomodulating and anti-tumor effects by increasing MHC class I molecule expression and affecting the activation, proliferation, differentiation, and survival of different immune cells. ${ }^{18,19}$ Furthermore, IFN- $\alpha$ has anti-angiogenic effects on tumor endothelial cells by inhibiting the expression of proangiogenic molecules, such as basic fibroblast growth factor or vascular endothelial growth factor. ${ }^{20,21}$ In vitro and in vivo studies using exogenously administered or endogenously expressed IFN- $\alpha$, targeting several types of cancer, confirmed its activity in cancer therapy. ${ }^{22,23}$ Its anti-tumor effects have been ascribed predominantly to its effects on hematopoietic-derived host cells and promotion of the cancer immunoediting process. ${ }^{12,24}$ In case of synchronous expression of IFN- $\alpha$ and IFN- $\gamma$, controversial effects have been reported.

The elucidation of potential differential and/or overlapping effects of IFN- $\alpha-$ versus IFN- $\gamma-$ driven tumor microenvironments on prognosis in CRC requires specific marker proteins that allow discriminating between the activities of both cytokines on their target cells. The identification and validation of biomarkers of cytokine activity in human tissues is of increasing importance because the clinical relevance of murine models specifically in inflammation-associated diseases remains in discussion. ${ }^{25}$ The human myxovirus resistance protein $\mathrm{A}(\mathrm{MxA})$ is among the major IFN- $\alpha$-induced proteins, ${ }^{26,27}$ both in human nonmalignant and malignant cells. $^{28-31}$ The expression of human guanylate-binding protein-1 (GBP-1) is strongly up-regulated by IFN- $\gamma$ in a variety of cells and is associated with reduced angiogenesis in CRC tissues and significantly prolonged cancer-specific 5-year survival of the respective patients. ${ }^{11,32,33}$ Herein, we established specific detection systems for both proteins and validated their use as biomarkers for IFN- $\alpha$ and IFN- $\gamma$ activation, respectively. By using these tools, we determined the differential impact of IFN- $\alpha-$ and IFN- $\gamma$-driven micromilieus on the prognosis of patients with colon carcinoma.

\section{Materials and Methods}

\section{Cell Culture and Stimulation of Cells}

Peripheral blood mononuclear cells (PBMCs) were separated by density-gradient centrifugation (Pancoll; PAN Biotech, Aidenbach, Germany) from leukapheresis products obtained from healthy volunteers. Monocytes were separated from PBMCs by countercurrent elutriation, as described previously, ${ }^{34}$ and cultivated in RPMI 1640 medium (PAA Laboratories, Pasching, Austria) supplemented with $10 \%(\mathrm{v} / \mathrm{v})$ fetal calf serum (FCS; Biochrom, Berlin, Germany) and $2 \mathrm{mmol} / \mathrm{L}$ L-glutamine (PAA Laboratories). $\mathrm{CD}^{+}$and $\mathrm{CD}^{+}{ }^{+}$cells were enriched from PBMCs via a negative isolation strategy using the $\mathrm{CD}^{+}$and $\mathrm{CD} 8^{+}$ T Cell Isolation Kit II (Miltenyi Biotec, Bergisch-Gladbach, Germany), according to the manufacturer's instructions. ${ }^{35}$ $\mathrm{CD} 4^{+} \mathrm{T}$ cells and $\mathrm{CD} 8^{+} \mathrm{T}$ cells were mixed in a physiological ratio before use and hereinafter referred to as $\mathrm{T}$ cells. Primary human umbilical vein endothelial cells (HUVECs; Lonza, Cologne, Germany) were cultivated in endothelial basal medium 2 completed with supplement and growth factors (Lonza). Primary normal human dermal fibroblasts (NHDFs; Promocell, Heidelberg, Germany) were cultured in Dulbecco's modified Eagle's medium (PAA Laboratories) supplemented with 10\% (v/v) FCS (Biochrom) and 2 $\mathrm{mmol} / \mathrm{L}$ L-glutamine (PAA Laboratories). The human colorectal adenocarcinoma cell line HT29 (ATCC, Manassas, VA) was maintained in McCoy's 5A (PAA Laboratories) supplemented with 10\% FCS (Biochrom) and 2 $\mathrm{mmol} / \mathrm{L}$ L-glutamine (PAA Laboratories). The colorectal carcinoma cell line T84 was cultivated in Dulbecco's modified Eagle's medium/Ham's (PAA Laboratories) with $5 \%$ FCS (Biochrom) and $2 \mathrm{mmol} / \mathrm{L}$ L-glutamine (PAA Laboratories). All cells were cultured at $37^{\circ} \mathrm{C}$ in a humidified atmosphere with $5 \% \quad \mathrm{CO}_{2} \quad(\mathrm{~T}$ cells, monocytes, HUVECs, HT29 cells, and T84 cells) or $8.5 \% \mathrm{CO}_{2}$ (NHDF). All cells, except HUVECs, were maintained in uncoated culture flasks (NUNC; Thermo Fisher Scientific, Waltham, MA). Flasks for HUVEC cultivation were coated for at least 2 hours with $1.5 \%$ bovine skin gelatin, type B (Sigma Aldrich, Taufkirchen, Germany) in PBS (Biochrom). All cells were monthly tested for mycoplasma contamination using the MycoAlert Mycoplasma Detection Kit (Lonza) and were, in all cases, negative. Before stimulation, all cells were starved overnight in basal medium containing $0.5 \%$ FCS, with the exception of purified T cells. Subsequently, cells were stimulated with $100 \mathrm{U} / \mathrm{mL}$ recombinant IFN- $\alpha$ (PeproTech, Rocky Hill, NJ), 100 U/mL recombinant IFN- $\gamma$ (Roche, Mannheim, Germany), or 100 $\mathrm{U} / \mathrm{mL}$ recombinant IFN- $\alpha$ and $100 \mathrm{U} / \mathrm{mL}$ recombinant IFN$\gamma$ in combination in the same medium for 24 hours. All 
cytokines were diluted in PBS containing $0.1 \%$ (w/v) bovine serum albumin (Sigma Aldrich). In all experiments, $\mathrm{PBS} / 0.1 \%$ bovine serum albumin was used as a control.

\section{Patients}

Experimental results are based on specimens and prospectively collected data from patients with well-documented colorectal carcinomas, who underwent surgery at the Department of Surgery in the University Medical Center Erlangen (Erlangen, Germany). For the pilot experiment, 33 colorectal carcinomas with the Union for International Cancer Control stages (UICC) ${ }^{36}$ I to IV and their corresponding healthy tissues were included for the initial immunohistochemical (IHC) analysis $(n=25$; stage I: $n=7$, stage II: $n=8$, stage III: $n=6$, stage IV: $n=4$; cecum: $n=3$, ascending colon: $n=5$, hepatic flexure: $n=2$, transverse colon: $n=1$, sigmoid colon: $n=5$, rectum: $n=9$ ) and in situ hybridization $(n=8 ; n=2$ per UICC stage I to IV; ascending colon: $n=1$, hepatic flexure: $n=1$, transverse colon: $n=1$, sigmoid colon: $n=1$, rectum: $n=4$ ).

Patients included in the TMA underwent surgery from 1991 to 2001 at the Department of Surgery in the University Medical Center Erlangen. All investigations were performed in accordance with the Declaration of Helsinki. The median follow-up was 10 years (range, 0 to 20 years). Patients and tumor characteristics are given in Table 1. Inclusion criteria of the patients were solitary invasive colon carcinoma (UICC stage II to IV) without appendix carcinoma, no other synchronous or previous malignant tumors (except squamous and basal cell carcinomas of the skin and carcinoma in situ of the cervix uteri), no familial adenomatous polyposis, no ulcerative colitis, and no Crohn's disease. Unfortunately, data on Amsterdam or Bethesda criteria or microsatellite status were not available for the whole study group. The tumor sites were right colon (cecum and ascending colon), transverse colon and flexures (hepatic flexure, transverse colon, and splenic flexure), and left colon (descending colon and sigmoid colon). The extent of surgery was determined by the localization of the tumor and its potential lymphatic spread. Thus, patients with tumors located between two drainage areas (transverse colon, hepatic flexure, or splenic flexure) are treated with extended hemicolectomies or subtotal colectomies with dissection of two or more lymphatic drainage areas. The median number of histologically examined lymph nodes was 33 (range: 4 to 117). Only patients without neoadjuvant treatment and residual tumor classification R0 were included. Patients who died postoperatively and patients with unknown tumor status (with respect to local and distant recurrence) at the end of the study were excluded. A total of 183 (48.4\%) of 378 patients died; 89 patients (23.5\%) of the 183 died of colon carcinoma and 195 (51.6\%) of the 378 were alive at the time of compilation of this article. General epidemiological data, clinical findings, treatment, histopathological examination, and follow-up data were collected prospectively. Detailed documentation of the histopathological findings allowed classification of the carcinomas in accordance with the seventh edition of the TNM
Table 1 Patient and Tumor Characteristics of Colon Carcinoma Patients Included in the TMA Analysis $(n=378)$

\begin{tabular}{|c|c|c|}
\hline Characteristics & Value $(n=378)$ & $\%$ \\
\hline Male:female ratio & $231: 147=1.63$ & NA \\
\hline Median/range age (years) & $64.0 / 28-91$ & NA \\
\hline \multicolumn{3}{|l|}{$\begin{array}{l}\text { MxA expression in the } \\
\text { desmoplastic stroma* }\end{array}$} \\
\hline MxA-negative stromal cells & 208 & 56.2 \\
\hline MxA-positive stromal cells & 162 & 43.8 \\
\hline MxA-negative tumor cells & 174 & 47.9 \\
\hline MxA-positive tumor cells & 189 & 52.1 \\
\hline \multicolumn{3}{|l|}{$\begin{array}{l}\text { GBP-1 expression in the } \\
\text { desmoplastic stroma }{ }^{\dagger}\end{array}$} \\
\hline GBP-1-negative stromal cells & 217 & 68.2 \\
\hline GBP-1-positive stromal cells & 101 & 31.8 \\
\hline \multicolumn{3}{|l|}{ Tumor site } \\
\hline Right colon & 97 & 25.7 \\
\hline Transverse colon and flexures & 84 & 22.2 \\
\hline Left colon & 197 & 52.1 \\
\hline \multicolumn{3}{|l|}{ Pathological stage (UICC 2009) } \\
\hline II & 189 & 50.0 \\
\hline III & 155 & 41.0 \\
\hline IV & 34 & 9.0 \\
\hline \multicolumn{3}{|l|}{ pT category } \\
\hline рT2 & 26 & 6.8 \\
\hline pT3 & 303 & 80.2 \\
\hline pT4 & 49 & 13.0 \\
\hline \multicolumn{3}{|l|}{ pN category } \\
\hline pNO & 198 & 52.4 \\
\hline $\mathrm{pN} 1$ & 107 & 28.3 \\
\hline pN2 & 73 & 19.3 \\
\hline \multicolumn{3}{|l|}{ Distant metastases } \\
\hline MO & 344 & 91.0 \\
\hline M1 & 34 & 9.0 \\
\hline \multicolumn{3}{|l|}{ Histopathological grading } \\
\hline Low grade $\left(\mathrm{G}_{1} / \mathrm{G}_{2}\right)$ & 309 & 81.7 \\
\hline High grade $\left(\mathrm{G}_{3} / \mathrm{G}_{4}\right)$ & 69 & 18.3 \\
\hline \multicolumn{3}{|l|}{ Lymphatic venous invasion } \\
\hline LO & 139 & 36.8 \\
\hline L1 & 239 & 63.2 \\
\hline \multicolumn{3}{|l|}{ Venous invasion $\ddagger$} \\
\hline V0 & 311 & 82.5 \\
\hline V1 & 66 & 17.5 \\
\hline \multicolumn{3}{|l|}{ Postoperative treatment } \\
\hline No & 304 & 80.6 \\
\hline Adjuvant chemotherapy & 55 & 14.5 \\
\hline Adjuvant radiotherapy & 1 & 0.3 \\
\hline Adjuvant chemoradiotherapy & 7 & 1.9 \\
\hline $\begin{array}{l}\text { Neoadjuvant chemotherapy before } \\
\text { resection of synchronous liver } \\
\text { metastases }\end{array}$ & 10 & 2.7 \\
\hline \multicolumn{3}{|l|}{ Emergency presentation } \\
\hline No & 335 & 88.6 \\
\hline Yes & 43 & 11.4 \\
\hline
\end{tabular}

${ }^{*} \mathrm{MxA}$ expression in stromal and tumor cells was not determined in 8 and 15 patients, respectively.

${ }^{\dagger} \mathrm{GBP}-1$ was not expressed in tumor cells. GBP-1 expression in stromal cells was not determined in 60 patients.

${ }^{\ddagger}$ Venous invasion of one patient was unknown.

NA, not applicable; UICC, Union for International Cancer Control. 
classification of the UICC. ${ }^{36}$ Histopathological grading was in accordance with the categories low and high, according to World Health Organization recommendations. ${ }^{37}$ Emergency presentation was defined as the need for an urgent surgery within 48 hours of admission. ${ }^{38}$

Postoperative chemotherapy with 5-fluorouracil was introduced in 1995 on a case-by-case basis. Sixty-five patients had postoperative chemotherapy (55 for adjuvant treatment and 10 with stage IV in neoadjuvant intent after primary tumor surgery before resection of liver metastases). The low rate of adjuvant chemotherapy in stage III patients (54/155) is also the result of participation in a randomized trial comparing adjuvant chemotherapy with no chemotherapy in stage III colon carcinoma. ${ }^{39}$ In addition, eight patients with sigmoid carcinomas received postoperative radiotherapy ( $n=1$ ) or chemoradiotherapy $(n=7)$.

All patients were scheduled to be reviewed at 3-month intervals for 2 years, and every 6 months thereafter, for a total of 5 years. Evaluations consisted of a thorough medical history, physical examination, blood cell counts, and blood chemistry, including carcinoembryonic antigen levels at every follow-up visit. A follow-up schedule for abdominal ultrasonography, computed tomographic scans of the abdomen and pelvis, and chest X-rays was also applied at regular intervals. Histological confirmation of suspected locoregional and distant relapse was always attempted but not always possible. In this case, progressive radiological enlargement of the suspicious mass was accepted as confirmatory. Isolated elevation of carcinoembryonic antigen levels, liver function test elevations, or suspicious findings alone were not recorded as treatment failure. After scheduled follow-up, at least vital status has been checked annually through inquiries at the patients' local registration office. At the end of the study, 183 patients (48.4\%) had died (84 related to colon carcinoma, 5 postoperative deaths after surgery for recurrence, 8 owing to other malignancies, and 86 from other nonmalignant diseases).

\section{TMA Data}

The tissue microarrayer (Beecher Instruments, Sun Prairie, WI) was used as follows: cores of $0.6-\mathrm{mm}$ diameter were punched from the donor blocks and positioned in a recipient paraffin array block in smaller holes of $0.4 \mathrm{~mm}$ for best adhesion of the samples to the array block. The design of the TMA was described previously. ${ }^{11}$ In brief, the 14 paraffin array blocks of the TMA were composed of three punch biopsy specimens of the tumor center and three punch biopsy specimens of the adjacent desmoplastic stroma. In total, 378 patients were available for staining and evaluation. Tumor and stromal cells of each punch were evaluated by two independent investigators (S.G. and U.S.) and were scored for number of stained cells and staining intensity. ${ }^{11}$ The final score was an average value of the three punches of the tumor center and the desmoplastic stroma. The evaluated punches of the tumor center and desmoplastic stroma for tumor and stromal cells are summarized in Table 2. Punches that were not evaluated because of loss during the staining procedure or because of lack of evaluable cell types are indicated as not applicable.

\section{Immunofluorescence Staining}

Immunofluorescence double staining of MxA in combination with CD3, CD31, CD68, or vimentin on paraformaldehydefixed, paraffin-embedded tissue sections required dewaxing of the tissue sections $(4 \mu \mathrm{m})$ and rehydration before antigen retrieval using Target Retrieval solution $\mathrm{pH} 9.0$ for $20 \mathrm{mi}-$ nutes at $95^{\circ} \mathrm{C}$ (Dako, Hamburg, Germany). Staining procedure was performed as previously described. ${ }^{40}$ The mouse monoclonal anti-human MxA antibody (IgG2a, clone M143) was diluted 1:20 in 5\% goat normal serum (Dianova, Hamburg, Germany) and applied in combination with the following: i) mouse monoclonal anti-cytokeratin antibody (1:50, clone AE1/AE3; IgG1, Diagnostic BioSystems, Pleasanton, CA), ii) rabbit monoclonal anti-CD3 antibody (1:50, clone SP7; Thermo Fisher Scientific), iii) mouse monoclonal anti-CD31 antibody $(1: 10, \operatorname{IgG1}$, clone JC70A; Dako), iv) mouse monoclonal anti-CD68 antibody (1:20, IgG3, clone PG-M1; Dako), or v) mouse monoclonal antivimentin antibody (1:200, IgM, clone VIM-13.2; Sigma Aldrich). According to the numeration previously mentioned, detection of the primary antibodies was performed by adding as secondary antibodies (1:500;

Table 2 MxA Is Expressed in Stromal and Tumor Epithelial Cells of Colon Carcinoma

\begin{tabular}{|c|c|c|c|c|c|c|c|c|}
\hline \multirow[b]{2}{*}{ Punch } & \multirow[b]{2}{*}{ Cell type } & \multicolumn{2}{|c|}{ MxA expression [no. (\%)] } & \multirow[b]{2}{*}{ Category } & \multicolumn{3}{|c|}{ MxA expression [no. (\%)]* } & \multirow{2}{*}{$\begin{array}{l}\text { No. not } \\
\text { applicable }\end{array}$} \\
\hline & & Negative & Positive & & Low & Intermediate & High & \\
\hline \multirow[t]{4}{*}{ Tumor center } & Tumor cells & $157(47.6)$ & $173(52.4)$ & Cell number & $32(18.5)$ & $70(40.5)$ & $71(41.0)$ & 48 \\
\hline & & & & Expression intensity & $45(26.0)$ & $81(46.8)$ & $47(27.2)$ & \\
\hline & Stromal cells & $188(53.3)$ & $165(46.7)$ & Cell number & $37(22.4)$ & $99(60.0)$ & $29(17.6)$ & 25 \\
\hline & & & & Expression intensity & $46(27.9)$ & $90(54.5)$ & $29(17.6)$ & \\
\hline \multirow{4}{*}{$\begin{array}{l}\text { Desmoplastic } \\
\text { stroma }\end{array}$} & Tumor cells & $174(47.9)$ & $189(52.1)$ & Cell number & $37(19.6)$ & $86(45.5)$ & $66(34.9)$ & 15 \\
\hline & & & & Expression intensity & $52(27.5)$ & $87(46.0)$ & $50(26.5)$ & \\
\hline & Stromal cells & $208(56.2)$ & $162(43.8)$ & Cell number & $31(19.1)$ & $85(52.5)$ & $46(28.4)$ & 8 \\
\hline & & & & Expression intensity & $40(24.7)$ & $92(56.8)$ & $30(18.5)$ & \\
\hline
\end{tabular}

*The relative percentage was calculated from MxA-positive patients.

${ }^{\dagger}$ Not applicable punches were not included in the calculation of relative percentages. 
Life Technologies, Darmstadt, Germany) for MxA a goat anti-mouse Alexa546 $\operatorname{IgG} 2 \mathrm{a}$ in combination with the following: i) goat anti-mouse IgG1 Alexa488, ii) goat antirabbit Alexa488, iii) goat anti-mouse IgG1 Alexa488, iv) goat anti-mouse IgG3 Alexa488, or v) goat anti-mouse IgM Alexa488. The nuclei were counterstained with Draq5 (1:800; Cell Signaling Technology, Danvers, MA), and slides were mounted with fluorescence medium (Dako). Double staining was analyzed using a Leica SPE LSM (Leica, Mannheim, Germany) equipped with the LAS-AF software version 2.6.0.7266 (Leica).

\section{IHC Staining}

IHC staining for MxA and GBP-1 on paraformaldehydefixed, paraffin-embedded tissue sections was performed as described previously. ${ }^{17,33}$ Antigen retrieval was performed as previously described. Human GBP-1 and human MxA were detected with rat monoclonal anti-GBP-1 antibody (clone $1 \mathrm{~B} 1,{ }^{17,33} 1: 300$ ) and mouse monoclonal anti-MxA antibody (clone M143, ${ }^{41,42}$ 1:200), respectively. Mouse IgG2a isotype control antibody (R\&D Systems, WiesbadenNordenstadt, Germany) was used as an control for MxA in corresponding concentrations. The staining was detected using the ABC Vectastain Elite kit (Vector Laboratories, Burlingame, CA) and NovaRed substrate (Vector Laboratories), according to the manufacturer's instructions. Slides were counterstained with Gill-III hematoxylin (Merck, Darmstadt, Germany), dehydrated, and mounted with VectaMount permanent mounting medium (Vector Laboratories). Sections were analyzed with a Leica DM6000 B or a Leica Aristoplan microscope (Leica).

\section{In Situ Hybridization with ${ }^{35} \mathrm{~S}$-Labeled Probes}

Specimens were processed as described previously. ${ }^{43,44}$ As a template for in vitro transcription, a specific sequence of $M X 1$ (NM_002462.3, 395 to 1412 bp) was cloned in both directions into a pcDNA4/myc-His B (Life Technologies) expression vector. A T7 Polymerase (Agilent Technologies, Böblingen, Germany) was used for the transcription of ${ }^{35}$ S-labeled RNA hybridization probes in sense and antisense directions. After autoradiography, sections were stained with Gill-III hematoxylin (Merck) and eosin (Sigma Aldrich). The slides were mounted using Pertex (Medite, Burgdorf, Germany) and visualized at a Leica DM6000 B or a Leica Aristoplan microscope (Leica) coupled to a charge-coupled device live camera (Sony, Berlin, Germany). The signals were analyzed in the bright field (expression signals appear as black silver grains) and in the dark field (light scattering by the silver grains produces white signals). As a negative control, hybridization of the $M X 1$ sense strand was used and the positive control was performed using an antisense probe for $A C T B$ (NM_001101.3, 172 to $1127 \mathrm{bp}$ ) cloned in the same vector as $M X 1$.

\section{Western Blot Analysis}

Preparation of cell extracts was performed as described previously. ${ }^{45}$ Protein concentration was determined using the detergent-compatible assay (Bio Rad, Munich, Germany). Cell extracts $(10 \mu \mathrm{g})$ were separated by electrophoresis on a $10 \%$ SDS-PAGE and subsequently analyzed by using Western blot analysis, as previously described, ${ }^{33}$ with the exception that membrane blocking was performed in PBS containing 5\% skim milk for 2 hours at room temperature. The following primary antibodies were diluted in PBS $/ 2.5 \%$ skim milk: rat monoclonal anti-GBP-1 antibody (clone 1B1, 1:500), mouse monoclonal anti-MxA antibody (clone M143, 1:1000), and mouse monoclonal anti-glyceraldehyde-3phosphate dehydrogenase antibody (MAB 374, 1:40,000; Millipore, Schwalbach, Germany). Rabbit anti-rat and rabbit anti-mouse IgG antibody coupled to horseradish peroxidase (1:5000; Dako) were used as secondary antibodies. Protein detection was performed using the enhanced chemiluminescence Western blot analysis detection system (Thermo Fisher Scientific) and Rx-films (Fuji, Tokyo, Japan).

\section{Statistical Analysis}

Statistical analysis of the TMA was performed as already described using SPSS software, version 19.0 (IBM, Ehningen, Germany). ${ }^{11}$ The $\chi^{2}$ analysis was used to compare frequencies. The Kaplan-Meier method with log-rank test was used to calculate and compare the rate of distant metastases, cancer-specific survival, and locoregional recurrence. In cancer-specific survival, an event was defined as death from colon carcinoma, because of either recurrence (locoregional or distant) or postoperative death after reoperation. The cancer-specific survival is influenced by the therapy of recurrence. The 95\% CIs for univariate analysis were calculated according to Greenwood. ${ }^{46}$ Multivariate Cox regression analysis was performed to identify independent prognostic factors. Factors that were found to be significant in one of the univariate analysis were included in the multivariate model. $P$ values were considered to be statistically significant when $P<0.05$.

\section{Results}

\section{MxA Expression Is Induced by IFN- $\alpha$ and GBP-1 Expression by IFN $-\gamma$ and IFN- $\alpha$}

To confirm the induction of MxA and GBP-1 by IFN- $\alpha$ and IFN- $\gamma$, different human cell lines and primary cells were treated with these cytokines, single or in combinations. Western blot analyses of the cell extracts showed that MxA is expressed after induction with IFN- $\alpha$ but not after induction with IFN- $\gamma$ and that MxA expression through IFN- $\alpha$ is not impaired by simultaneous presence of IFN- $\gamma$ in freshly purified $\mathrm{T}$ cells and monocytes, primary endothelial 
cells (HUVECs), primary NHDFs, and colorectal carcinoma cell lines (HT29 and T84) (Figure 1). MxA was not expressed in unstimulated cells with the exception of freshly purified monocytes, in which a basal level of expression was noted in untreated cells, which was not affected by IFN- $\gamma$ treatment (Figure 1). GBP-1 was strongly induced on treatment with IFN- $\gamma$ in all cells analyzed (Figure 1). IFN- $\alpha$ induced GBP-1 expression slightly in T cells, monocytes, HUVECs, and NHDF cells (Figure 1). GBP-1 was expressed at low levels in T cells, monocytes, and NHDF in the absence of stimulation (Figure 1). Costimulation of the cells with IFN- $\alpha$ and IFN- $\gamma$ did not significantly increase the expression levels of GBP-1 compared with IFN- $\gamma$ alone (Figure 1). In conclusion, MxA was selectively induced by IFN- $\alpha$, and GBP- 1 strongly by IFN- $\gamma$ and weakly by IFN- $\alpha$, in different CRC stroma and tumor cells.

\section{MxA and GBP-1 Are Expressed in CRC}

Our group has previously described the staining of GBP-1 in CRC tissues ${ }^{11,47}$; however, MxA expression in CRC has not yet been described. Therefore, sensitive and specific IHC detection of MxA was established in a pilot study using primary colorectal carcinoma tissues and corresponding tumor-free mucosa of patients, which were previously shown to be positive for GBP-1 $(n=25)$. MxA was strongly expressed in the tumor cells $(n=20)$ (Figure 2A) and in cells of the desmoplastic stroma $(n=25)$ (Figure 2A). In contrast, GBP-1 was mainly detected in the desmoplastic stroma (Figure 2A) and only rarely in the tumor cells $(n=2)$ (Figure 2A). Consecutive isotypespecific control staining of tumor tissue showed no unspecific reaction (Figure 2A). The adjacent healthy mucosa tissue showed rare and only weak expression of MxA $(n=9)$ and GBP-1 $(n=6)$. To determine the nature of the MxA-expressing cells, double immunofluorescence staining using cell type-specific markers was performed. Most of the MxA-positive cells were found to be of tumor epithelial origin (Supplemental Figure S1A). In addition, MxA expression was detected in $\mathrm{T}$ lymphocytes (Supplemental
Figure S1B), endothelial cells (Supplemental Figure S1C), monocytes/macrophages (Supplemental Figure S1D), and fibroblasts (Supplemental Figure S1E) of the desmoplastic stroma. The results on the detection of MxA protein were confirmed at the RNA level by in situ hybridization (ISH) in CRC tissues $(n=8)$. ISH with a radiolabeled strandspecific antisense RNA probe specific for $M X 1$-mRNA revealed signals in the tumor cells and in the stromal cells of CRC tissues (Figure 2B), but not in the healthy mucosa (Figure 2C). No unspecific signals were obtained with the sense control probe in tumor tissue and healthy mucosa (Figure 2, B and C). ISH results correlated well with IHC performed on consecutive CRC tissue sections (Figure 2B). These results confirmed the specificity of the MxA staining in CRC.

\section{Stromal Expression of MxA and GBP-1 Is Associated with an Increased Cancer-Specific 5-Year Survival and a Decreased Rate of Distant Metastases in Patients with Colon Carcinoma}

A potential differential clinical impact of an IFN- $\alpha-$ and an IFN- $\gamma$-driven tumor microenvironment in colon carcinoma was analyzed by IHC staining of MxA and GBP-1 in a large cohort of well-characterized patients with colon carcinoma using a TMA. Punches were obtained from two distinct locations, the tumor center and the desmoplastic stroma. The TMA was composed of formalin-fixed, paraffinembedded tissue punches of UICC stage II to IV colonic carcinomas $(n=378)$ with complete follow-up data available for statistical analysis. Standard patient and tumor characteristics of the cohort are given in Table 1. The 5-year rate of distant metastases of all 378 patients was $26.3 \%$ (Table 3). Of 378 patients, 102 developed distant metastases at one or more sites, 96 of them within the first 5 years. The 5 -year rate of locoregional recurrence was $6.4 \%$, and the 5year overall survival was $75.4 \%$. The 5 -year cancer-specific survival of all 378 patients was $81.5 \%$ (Table 4).

The evaluation criteria were classified into negative, low, intermediate, and high, according to cell number and
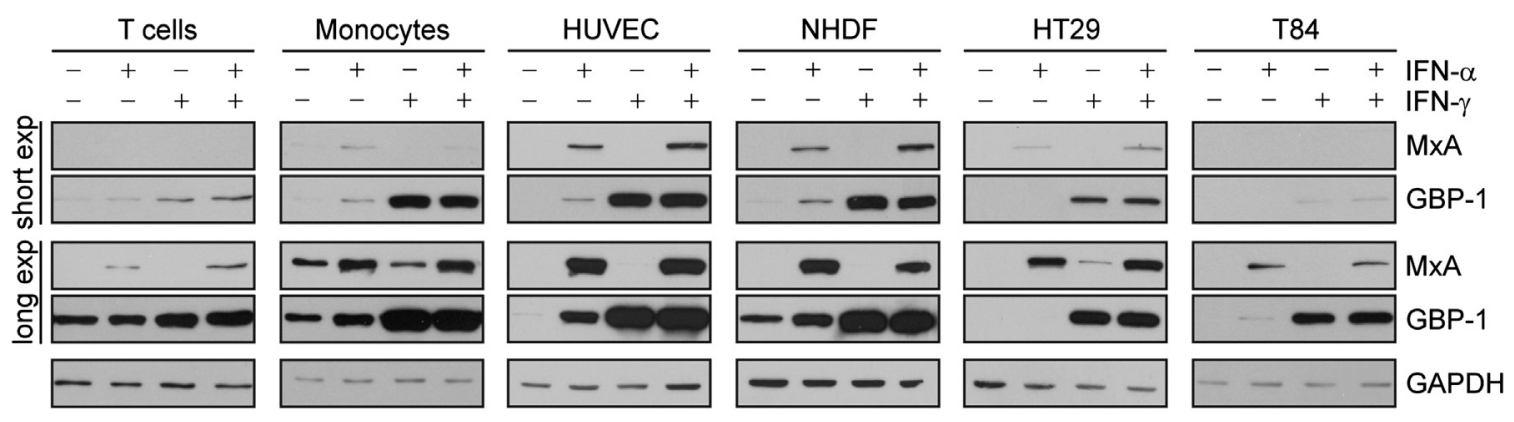

Figure 1 MxA expression is induced by IFN- $\alpha$ and GBP-1 expression by IFN- $\gamma$ and IFN- $\alpha$. Western blot analysis of MxA and GBP-1 expression in cell lysates of different cell types (T cells, monocytes, HUVECs, NHDFs, HT29 cells, and T84 cells). Cells were stimulated for 24 hours with $100 \mathrm{U} / \mathrm{mL}$ IFN- $\alpha$, IFN- $\gamma$, and IFN$\alpha /$ IFN- $\gamma$ or were left untreated (control). MxA and GBP-1 expression levels are depicted once after short exposure time (short exp $=1$ minute) and once after long exposure time (long exp = 1 hour), respectively. Detection of glyceraldehyde-3-phosphate dehydrogenase (GAPDH) shows that equal amounts of protein were loaded. 


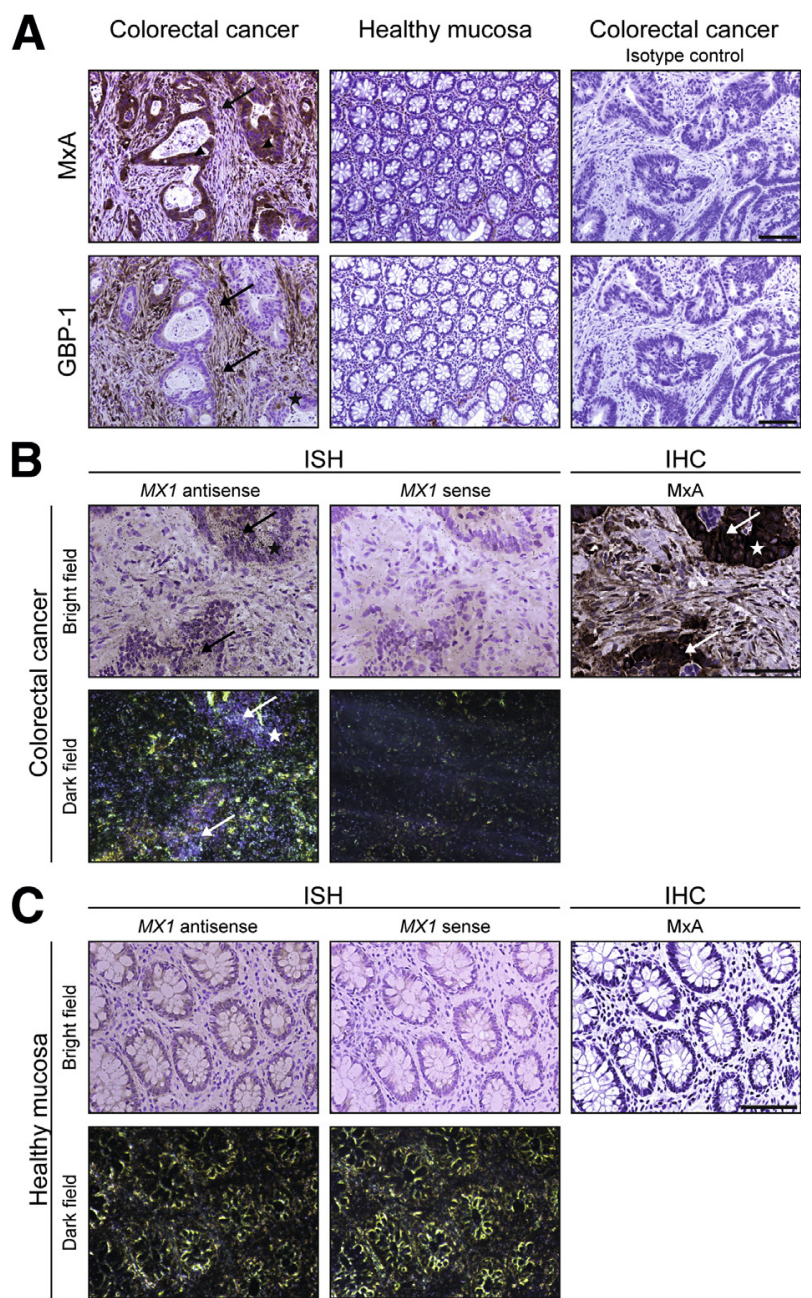

Figure $2 M \times A$ and GBP-1 are expressed in colorectal carcinoma. A: IHC staining of MxA and GBP-1 (brown) in consecutive sections of CRC and adjacent healthy mucosa. Isotype-specific control stainings were performed on CRC tissue. In the MxA row, arrowheads indicate MxA-positive tumor cells; arrow, MxA-positive stromal cells. In the GBP-1 row, arrows indicate GBP-1-positive stromal cells; asterisk, tumor area. ISH on CRC tissue sections (B) and on healthy mucosa (C) with Mx1-mRNA-specific antisense and control sense probes. Signals appear in the bright field as black grains and in the dark field as white grains and are indicated by arrows. Tumor area is indicated by an asterisk. IHC staining of MxA was performed on consecutive tissue sections. Scale bars: $100 \mu \mathrm{m}$ (A); $50 \mu \mathrm{m}$ (B and C).

expression level (Supplemental Figure S2). IFN- $\alpha$-induced MxA was found to be expressed in approximately $50 \%$ of the colon carcinoma samples in the tumor cells $(52.4 \%$ tumor center region and $52.1 \%$ desmoplastic stroma region) (Table 2) and to a lesser extent in the stromal cells (46.7\% tumor center region and $43.8 \%$ desmoplastic stroma region) (Table 2). Most MxA-positive cases exhibited an intermediate MxA expression concerning both cell number and expression intensity independent of the cell type (Table 2). The remaining MxA-positive cases were almost equally distributed between low and high MxA expression (Table 2). In both punches of the tumor center region and the desmoplastic stroma region, high MxA expression was more frequently found in the tumor cells (2.33- or 1.23-fold, respectively) compared with the stromal cells (Table 2). MxA expression of neither tumor nor stromal cells was correlated with classic clinicopathological parameters, such as $\mathrm{pN}$ category or UICC stage (data not shown).

Interestingly, patients with MxA-positive stromal cells in the desmoplastic stroma region $(n=162)$ (Figure 3A) showed a significantly reduced 5-year rate of distant metastases (univariate analysis: MxA positive versus negative, $21.4 \%$ versus $30.8 \% ; P=0.040$ ) (Table 3 ) and a significantly increased cancer-specific 5-year survival (univariate analysis: MxA positive versus negative, $86.7 \%$ versus $77.1 \% ; P=0.040$ ) (Table 4) compared with MxA-negative patients $(n=208)$ (Figure 3A). Despite the high expression level of MxA in the tumor cells (previously described), positive signals in this cell compartment did not exhibit prognostic relevance for colon carcinoma (Supplemental Figure S3).

The same TMA including punches of the tumor center and desmoplastic stroma region with the identical cohort of patients was analyzed for IFN- $\gamma$-induced GBP-1 expression in a previous work. ${ }^{11}$ In the desmoplastic stroma region, GBP-1-positive stromal cells $(n=101)$ (Figure 3B) were associated with a significant decrease in the 5-year rate of distant metastases (univariate analysis: GBP-1 positive versus negative, $15.5 \%$ versus $32.6 \% ; P=0.001$ ) (Table 3 ) and a significant increase in cancer-specific 5-year survival (univariate analysis: GBP-1 positive versus negative, 91.6\% versus $76.8 \% ; P=0.001$ ) (Table 4 ) compared with patients not expressing GBP-1 $(n=217)$ (Figure 3B). Other wellestablished prognostic factors, such as UICC stage, pT, $\mathrm{pN}$, or M category, lymph, and venous invasion did correlate with increased survival, confirming the representative value of this study group (Tables 3 and 4). Multivariate Cox regression analysis showed an increased hazard ratio for both MxA (multivariate analysis: MxA-negative hazard ratios, 1.4 and 1.5) (Tables 3 and 4, respectively) and GBP-1 (multivariate analysis: GBP-1-negative hazard ratios, 1.6 and 1.6) (Tables 3 and 4, respectively), but without statistical significance.

\section{IFN- $\gamma$-Driven Intratumoral Microenvironment} Exhibits Superior Prognostic Effect Compared with an IFN- $\alpha$-Driven Microenvironment

The analyses of GBP-1 and MxA expression in the same TMA with an identical patient cohort enabled us to compare the impact of an IFN- $\alpha-$ and an IFN- $\gamma-$ driven tumor microenvironment on the patients' survival. Comparison of MxA expression and GBP-1 expression in stromal cells of the desmoplastic stroma region $(n=318)$ showed a significant correlation between both markers $\left(\chi^{2}\right.$ analysis: $P<$ $0.001)$.

No matter whether MxA was co-expressed or not, all patients with GBP-1 expression in the primary tumors exhibited a reduced 5-year rate of distant metastasis 
Table 3 Expression of MxA and GBP-1 in Desmoplastic Stromal Cells of the Stromal Region Is Associated with a Decreased 5-Year Rate of Distant Metastases in Colon Carcinoma

\begin{tabular}{|c|c|c|c|c|c|c|c|c|}
\hline \multirow[b]{2}{*}{ Characteristics } & \multicolumn{4}{|c|}{ Univariate analysis } & \multicolumn{4}{|c|}{ Multivariate analysis } \\
\hline & $n$ & $\begin{array}{l}5-y \text { rate of } \\
\text { distant } \\
\text { metastases (\%) }\end{array}$ & $\begin{array}{l}95 \% \mathrm{CI} \\
(\%)\end{array}$ & $P$ value & $n$ & Hazard ratio & $\begin{array}{l}95 \% \mathrm{CI} \\
(\%)\end{array}$ & $P$ value \\
\hline All patients & 378 & 26.3 & $21.8-30.8$ & & $317^{*}$ & & & \\
\hline \multicolumn{9}{|c|}{ MxA expression (desmoplastic stroma) } \\
\hline MxA-positive stromal cells & $162^{\dagger}$ & 21.4 & $14.9-27.9$ & 0.040 & 144 & 1.0 & & \\
\hline MxA-negative stromal cells & $208^{\dagger}$ & 30.8 & $24.3-37.3$ & & 173 & 1.4 & $0.9-2.3$ & 0.105 \\
\hline GBP-1-positive stromal cells & $101^{\ddagger}$ & 15.5 & $8.3-22.8$ & 0.001 & 100 & 1.0 & & \\
\hline GBP-1-negative stromal cells & $217^{\ddagger}$ & 32.6 & $26.3-38.9$ & & 217 & 1.6 & $0.9-2.8$ & 0.114 \\
\hline \multicolumn{9}{|l|}{$\begin{array}{l}\text { MXA and GBP-1 expression in the } \\
\text { desmoplastic stroma }\end{array}$} \\
\hline GBP-1 positive/MxA negative & 36 & 11.7 & $0.9-22.5$ & $0.005^{\S}$ & & & & \\
\hline GBP-1 positive/MxA positive & 65 & 17.6 & $8.2-27.0$ & $0.007^{\S}$ & & & & \\
\hline Transverse colon and flexures & 84 & 19.3 & $10.9-27.7$ & & & & & \\
\hline Left colon & 197 & 28.0 & $18.6-37.4$ & & & & & \\
\hline \multicolumn{9}{|l|}{ Pathological stage (UICC 2009) } \\
\hline II & 189 & 11.8 & $7.1-16.5$ & $<0.001$ & 156 & 1.0 & & \\
\hline III & 155 & 35.5 & $27.9-43.1$ & & 132 & 2.3 & $1.4-3.9$ & 0.002 \\
\hline IV & 34 & 63.5 & $47.0-80.0$ & & 29 & 7.0 & $3.8-13.2$ & $<0.001$ \\
\hline \multicolumn{9}{|l|}{ pT category } \\
\hline pT2 & 26 & 11.5 & $-0.9-23.9$ & 0.067 & & & & \\
\hline pT3 & 303 & 25.9 & $20.8-31.0$ & & & & & \\
\hline pT4 & 49 & 37.2 & $23.5-50.9$ & & & & & \\
\hline \multicolumn{9}{|l|}{ pN category } \\
\hline pNO & 198 & 12.8 & $8.1-17.5$ & $<0.001$ & & & & \\
\hline \multicolumn{9}{|l|}{ Lymph venous invasion } \\
\hline LO & 139 & 16.9 & $10.4-23.4$ & 0.002 & 111 & 1.0 & & \\
\hline L1 & 239 & 31.7 & $25.8-37.6$ & & 206 & 1.0 & $0.6-1.7$ & 0.932 \\
\hline \multicolumn{9}{|l|}{ Venous invasion } \\
\hline vo & $311^{\pi}$ & 20.4 & $15.9-24.9$ & $<0.001$ & 257 & 1.0 & & \\
\hline V1 & $66^{\pi}$ & 54.6 & $42.5-66.8$ & & 60 & 2.8 & $1.8-4.5$ & $<0.001$ \\
\hline \multicolumn{9}{|l|}{ Chemotherapy } \\
\hline No & 305 & 24.7 & $19.8-29.6$ & 0.270 & & & & \\
\hline Yes & 72 & 32.4 & $21.4-43.4$ & & & & & \\
\hline \multicolumn{9}{|l|}{ Radiotherapy } \\
\hline No & 370 & 26.4 & $21.9-30.9$ & 0.860 & & & & \\
\hline Yes & 8 & 25.0 & $-5.0-55.0$ & & & & & \\
\hline \multicolumn{9}{|l|}{ Emergency presentation } \\
\hline No & 335 & 23.7 & $19.0-28.4$ & $<0.001$ & 283 & 1.0 & & \\
\hline Yes & 43 & 49.2 & $33.3-65.1$ & & 34 & 1.3 & $0.7-2.4$ & 0.368 \\
\hline
\end{tabular}

Univariate and multivariate analysis concerning the 5 -year rate of distant metastases are given. Multivariate analysis includes variables with significance $(P<0.05)$ in one of the univariate analyses.

${ }^{*} \mathrm{GBP}-1$ expression of 60 patients was not determined; venous invasion of one patient was unknown.

${ }^{\dagger} \mathrm{MxA}$ expression of eight patients was not determined.

${ }_{\mathrm{GBP}}^{\ddagger} 1$ expression of 60 patients was not determined.

${ }^{\S} P$ values refer to Kaplan-Meier analysis against GBP-1/MxA double-negative patients.

"Venous invasion of one patient was unknown.

UICC, Union for International Cancer Control. 
Table 4 Expression of MxA and GBP-1 in Desmoplastic Stromal Cells of the Stromal Region Is Associated with a Prolonged Cancer-Specific 5-Year Survival in Colon Carcinoma

\begin{tabular}{|c|c|c|c|c|c|c|c|c|}
\hline \multirow[b]{2}{*}{ Variable } & \multicolumn{4}{|c|}{ Univariate analysis } & \multicolumn{4}{|c|}{ Multivariate analysis } \\
\hline & $n$ & $\begin{array}{l}\text { Cancer-specific } \\
5-y \text { survival } \\
(\%)\end{array}$ & $\begin{array}{l}95 \% \\
\text { CI }(\%)\end{array}$ & $P$ value & $n$ & Hazard ratio & $\begin{array}{l}95 \% \\
\text { CI }(\%)\end{array}$ & $P$ value \\
\hline All patients & 378 & 81.5 & $77.6-85.4$ & & $317^{*}$ & & & \\
\hline \multicolumn{9}{|c|}{ MxA expression (desmoplastic stroma) } \\
\hline MxA-positive stromal cells & $162^{\dagger}$ & 86.7 & $81.4-92.0$ & 0.040 & 144 & 1.0 & & \\
\hline MxA-negative stromal cells & $208^{\dagger}$ & 77.1 & $71.2-83.0$ & & 173 & 1.5 & $0.9-2.5$ & 0.084 \\
\hline GBP-1-positive stromal cells & $101^{\ddagger}$ & 91.6 & $86.1-97.1$ & 0.001 & 100 & 1.0 & & \\
\hline GBP-1-negative stromal cells & $217^{\ddagger}$ & 76.8 & $71.1-82.5$ & & 217 & 1.6 & $0.8-3.0$ & 0.154 \\
\hline \multicolumn{9}{|l|}{$\begin{array}{l}\text { MXA and GBP-1 expression in the } \\
\text { desmoplastic stroma }\end{array}$} \\
\hline GBP-1 positive/MxA negative & 36 & 94.0 & $86.0-102.0$ & $0.006^{\S}$ & & & & \\
\hline GBP-1 positive/MxA positive & 65 & 90.3 & $82.9-97.8$ & $0.006^{\S}$ & & & & \\
\hline Transverse colon and flexures & 84 & 82.9 & $74.7-91.1$ & & & & & \\
\hline Left colon & 197 & 78.3 & $69.7-86.9$ & & & & & \\
\hline \multicolumn{9}{|l|}{ Pathological stage (UICC 2009) } \\
\hline II & 189 & 92.6 & $88.7-96.5$ & $<0.001$ & 156 & 1.0 & & \\
\hline III & 155 & 74.5 & $67.6-81.4$ & & 132 & 2.5 & $1.4-4.4$ & 0.002 \\
\hline IV & 34 & 54.7 & $37.7-71.8$ & & 29 & 4.8 & $2.4-9.7$ & $<0.001$ \\
\hline \multicolumn{9}{|l|}{ pT category } \\
\hline pT2 & 26 & 96.2 & $88.8-103.7$ & 0.021 & & & & \\
\hline pT3 & 303 & 82.7 & $78.4-87.0$ & & & & & \\
\hline pT4 & 49 & 66.4 & $52.9-79.9$ & & & & & \\
\hline \multicolumn{9}{|l|}{$\mathrm{pN}$ category } \\
\hline pNO & 198 & 90.8 & $86.7-94.9$ & $<0.001$ & & & & \\
\hline \multicolumn{9}{|l|}{ Lymph venous invasion } \\
\hline LO & 139 & 88.4 & $82.9-93.9$ & 0.003 & 111 & 1.0 & & \\
\hline $\mathrm{L} 1$ & 239 & 77.7 & $72.4-83.0$ & & 206 & 1.1 & $0.6-2.0$ & 0.636 \\
\hline \multicolumn{9}{|l|}{ Venous invasion } \\
\hline Vo & $311^{\pi}$ & 86.5 & $82.6-90.4$ & $<0.001$ & 257 & 1.0 & & \\
\hline V1 & $66^{\pi}$ & 57.5 & $45.4-69.7$ & & 60 & 2.5 & $1.5-4.1$ & $<0.001$ \\
\hline \multicolumn{9}{|l|}{ Chemotherapy } \\
\hline No & 305 & 82.8 & $78.5-87.1$ & 0.362 & & & & \\
\hline Yes & 72 & 76.0 & $66.0-86.0$ & & & & & \\
\hline \multicolumn{9}{|l|}{ Radiotherapy } \\
\hline No & 370 & 81.4 & $77.3-85.5$ & 0.976 & & & & \\
\hline Yes & 8 & 87.5 & $64.6-110.4$ & & & & & \\
\hline \multicolumn{9}{|l|}{ Emergency presentation } \\
\hline No & 335 & 84.2 & $80.3-88.1$ & $<0.001$ & 283 & 1.0 & & \\
\hline Yes & 43 & 59.0 & $43.5-74.5$ & & 34 & 1.9 & $1.0-3.4$ & 0.042 \\
\hline
\end{tabular}

Univariate and multivariate analyses concerning the cancer-specific 5 -year survival are given. Multivariate analysis includes variables with significance $(P<$ $0.05)$ in one of the univariate analyses.

*GBP-1 expression of 60 patients was not determined; venous invasion of one patient was unknown.

${ }^{\dagger} \mathrm{MxA}$ expression of eight patients was not determined.

${ }^{\ddagger} \mathrm{GBP}-1$ expression of 60 patients was not determined.

${ }^{\S} P$ values refer to Kaplan-Meier analysis against GBP-1/MxA double-negative patients.

TVenous invasion of one patient was unknown.

UICC, Union for International Cancer Control. 

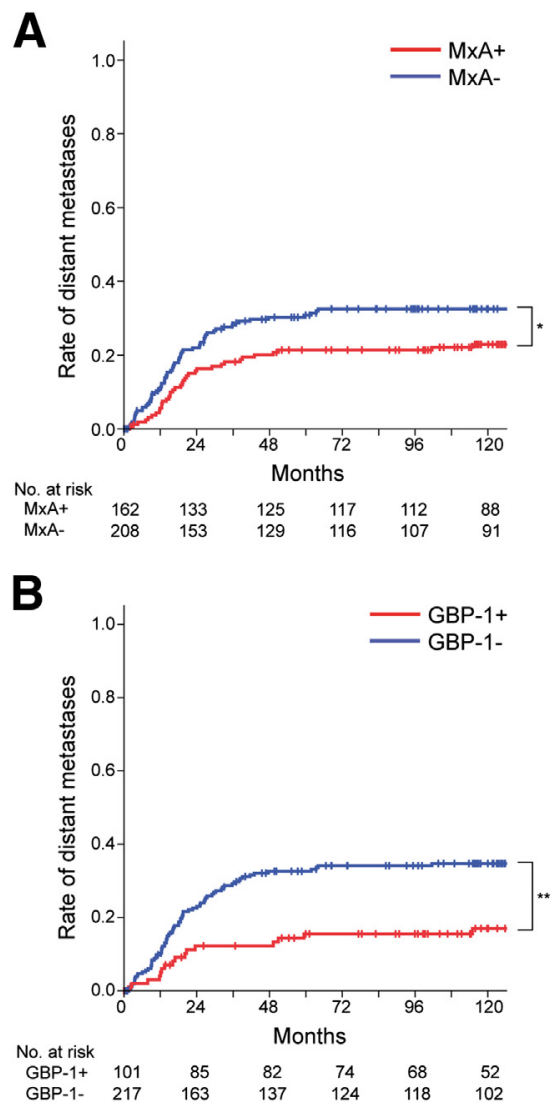
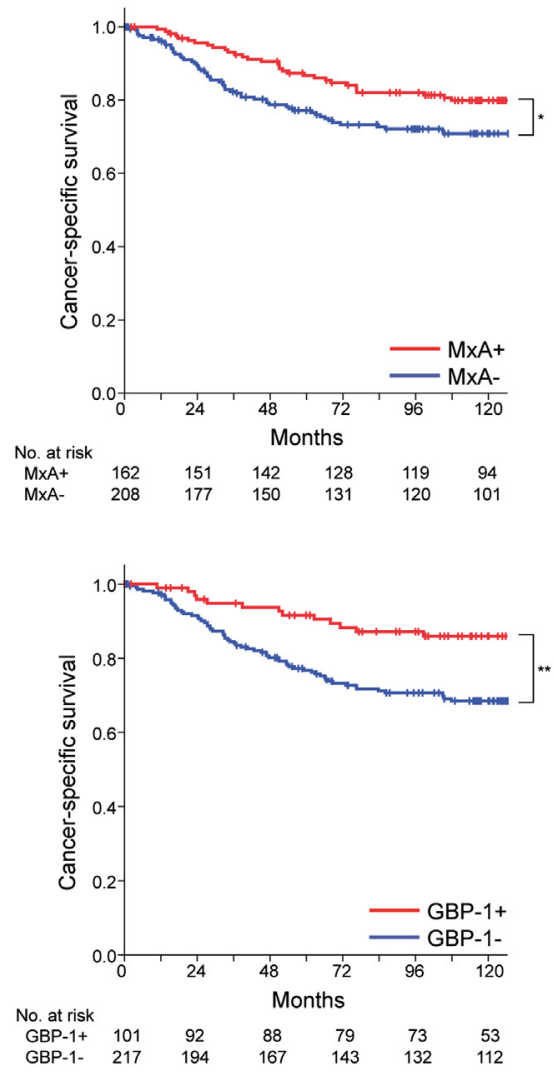

Figure 3 Stromal expression of MxA and GBP-1 is associated with an increased cancer-specific survival and a decreased rate of distant metastases in patients with colon carcinoma. A: Rate of distant metastases and cancer-specific survival of patients with colon carcinoma $(n=370)$ with MxA-positive (red curve, $n=162$ ) and MxAnegative (blue curve, $n=208$ ) stromal cells in the desmoplastic stroma region of the TMA are depicted by Kaplan-Meier-curves. B: Analyses of the rate of distant metastases and the cancerspecific survival of GBP-1-positive (red curve, $n=101$ ) and GBP-1-negative (blue curve, $n=$ 217) stromal cells in patients with colon carcinoma $(n=318)$ were calculated using the Kaplan-Meier method. ${ }^{*} P=0.040,{ }^{*} P=0.001$. (univariate analysis: GBP-1 positive/MxA negative, $11.7 \%$; GBP-1 positive/MxA positive, $17.6 \%$ ) (Table 3) and a significantly improved cancer-specific 5-year survival (univariate analysis: GBP-1 positive/MxA negative, 94\%; GBP1 positive/MxA positive, 90.3\%) (Table 4) compared with double-negative patients (Figure 4). Patients expressing exclusively MxA and not GBP-1, which indicates selective IFN- $\alpha$ activity in the absence of IFN- $\gamma$, also exhibited a lower 5-year rate of distant metastases of $26.6 \%$ (univariate analysis: GBP-1 negative/MxA positive) (Table 3) and an improved cancer-specific 5-year survival of $83.5 \%$ (univariate analysis: GBP-1 negative/MxA positive) (Table 4) compared with double-negative patients, but this difference was not statistically significant (Figure 4). In accordance with the differences in survival, the rate of distant metastases of GBP-1-positive patients was reduced compared with MxA-positive patients $(5.0 \%$ versus $10.0 \%)$ (Supplemental Table S1). Moreover, the distribution of the target organs involved was different between both patient groups. In MxA-positive patients, relatively higher frequencies of liver and lung involvement were observed compared with patients with GBP-1-positive tumors (GBP-1 positive: liver, 36.8\%; lung, 10.5\%; versus MxA positive: liver, 50.0\%; lung, 17.4\%) (Supplemental Table S1). In contrast, metastases to peritoneum and distant lymph nodes were more often observed in GBP-1-positive patients than in MxA-positive patients (GBP-1 positive: peritoneum, 5.3\%; distant lymph nodes, 21.1\%; versus MxA positive: peritoneum, 2.2\%; distant lymph nodes, 6.5\%) (Supplemental Table S1).

Altogether, these results revealed that an IFN- $\gamma-$ driven tumor microenvironment exerts a superior effect on patients' survival and outcome in colon carcinoma compared with microenvironments driven by IFN- $\alpha$ or without an IFN-associated immune reaction.

\section{Discussion}

The aim of the present study was to investigate a potential differential impact of IFN- $\alpha-$ and IFN- $\gamma-$ driven tumor microenvironments/immune reactions on the prognosis of patients with colon carcinoma. To comprehensively characterize the tumor microenvironment, our specific focus was not on the detection of the cytokines but on the detection of target cells that were exposed to and activated by the two different cytokines in the tissue. Therefore, we examined the expression of two specific marker proteins, human MxA and human GBP-1, in a large cohort of patients with colon carcinoma $(n=378)$. In agreement with previous results, GBP-1 was strongly induced in most cells by IFN- $\gamma$ and only slightly by IFN- $\alpha$ (Figure 1), ${ }^{33,48}$ whereas MxA was specifically induced by IFN- $\alpha$ (Figure 1). ${ }^{26,27}$ Because of their expression patterns, the two selected markers allowed us to clearly discriminate between IFN- $\alpha-$ and IFN- $\gamma-$ driven immune reactions in the tissues. The detection of 

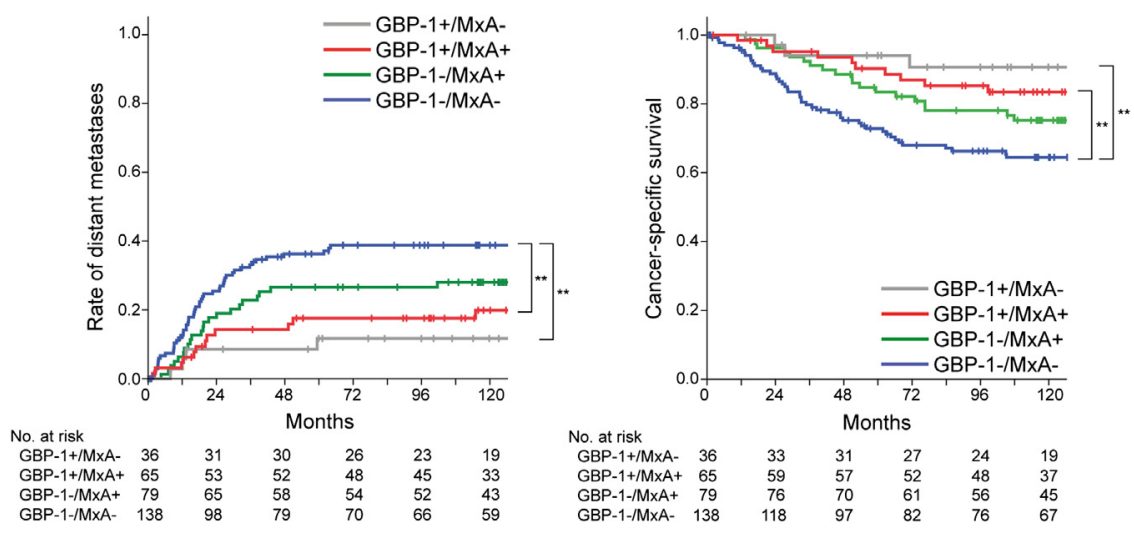

Figure 4 IFN- $\gamma$-driven intratumoral microenvironment exhibits superior prognostic effect compared with an IFN- $\alpha$-driven microenvironment. Association of MxA and GBP-1 expression in stromal cells of the desmoplastic stroma region of patients with colon carcinoma $(n=318)$ with rate of distant metastases and cancer-specific survival. Analyses are shown according to Kaplan-Meier method. ${ }^{* *} P<0.01$.
MxA indicates IFN- $\alpha$ activity, the detection of GBP-1 in the absence of MxA indicates IFN- $\gamma$ activity, and the simultaneous presence of MxA and GBP-1 is associated with a microenvironment defined by simultaneous activity of both interferons.

Previously, we demonstrated that GBP-1 expression in the primary tumors is associated with an improved prognosis of patients with CRC. ${ }^{11}$ Herein, we showed that MxA expression in colon carcinoma is also associated with a significantly increased cancer-specific 5-year survival and a decreased 5-year rate of distant metastases in MxA-positive patients with colon carcinoma.

Interestingly, MxA-expressing tumor cells in colon carcinoma were not associated with a significant impact on the clinical prognosis, whereas MxA expression in the desmoplastic stroma was associated with a significantly improved prognosis of the respective patients (Figure 3). This might be explained by the fact that IFN- $\alpha$ exerts its immunomodulating and anti-tumoral effects mainly on hematopoieticderived host cells and, thereby, promotes the cancer immunoediting processes. ${ }^{12,24}$ Endogenously produced IFN- $\alpha$ acts early during the development of the antitumor response and induces mainly dendritic cells to activate naive $\mathrm{CD}^{+}{ }^{+}$T cells. ${ }^{19}$ Moreover, IFN- $\alpha$ is described to have an influence on the motility and migration of $\mathrm{T}$ cells. ${ }^{49}$

The single and combined analysis of the expression of MxA and GBP-1 revealed that expression of MxA was associated with an improved prognosis of patients with colon carcinoma. This indicated that an IFN- $\alpha$-driven intratumoral immune reaction has a positive effect. However, prognosis of patients was further improved in patients expressing GBP-1 in the primary lesions, in agreement with previous results. ${ }^{11} \mathrm{GBP}-1$ alone cannot be used to differentiate between IFN- $\alpha$ and IFN$\gamma$ activation, suggesting that the improved prognosis may be the result of cooperative activity of both cytokines. However, in patients expressing only GBP-1 and not MxA, compared with those co-expressing both markers, the prognosis was further improved, but not in a statistically significant manner. There was no statistically significant difference regarding the clinicopathological criteria between these two groups. This clearly demonstrated the following: i) the IFN- $\gamma-$ driven immune reaction caused the GBP-1-associated improvement of prognosis, ii) this immune reaction has a superior prognostic effect compared with the IFN- $\alpha$-driven immune reaction, and iii) an IFN- $\gamma-$ and IFN- $\alpha$-driven immune reaction does not exert a significant cooperative effect. Accordingly, patients with only an IFN- $\gamma$-driven immune reaction tended to exhibit a better prognosis compared with those in whom both cytokines were active.

In the literature, the effects of IFN- $\alpha$ on IFN- $\gamma$ expression are discussed controversially and their simultaneous presence has been reported to cause agonistic and antagonistic effects. In favor of a positive cooperation, IFN- $\alpha$ and IFN- $\gamma$ exert cooperative anti-proliferative and pro-apoptotic activities on tumor cells in vitro and in vivo in a mouse model. ${ }^{50,51}$ In addition, IFN- $\alpha$ can promote Th1 differentiation by increasing IFN- $\gamma$ production and the numbers of IFN- $\gamma-$ producing natural killer and T cells. ${ }^{52-56}$ Agonistic activity has been observed by showing that IFN- $\alpha$ is able to suppress IFN- $\gamma$ production through inhibition of IL-12 production $^{57,58}$ by competing for STAT1 molecules ${ }^{59,60}$ and by inducing STAT1 inhibitors. ${ }^{61}$ Our findings suggest that the latter mechanisms may be partly operative in CRC.

The role of IFN- $\gamma$ in cancer immunosurveillance is well described and includes, in tumor cells, inhibition of proliferation, migration, and invasion and induction of $\operatorname{apoptosis}^{47}$; at the stromal cell level, it includes modulation of immune cell activity ${ }^{16}$ and inhibition of angiogenesis. ${ }^{11}$

In conclusion, our data demonstrate, for the first time to our knowledge, the superior prognostic impact of an IFN- $\gamma-$ driven tumor microenvironment in direct comparison to an IFN- $\alpha$-driven microenvironment. Moreover, the results present a successful proof-of-principle approach that complex cytokine interaction networks can be functionally dissected in human tissues with great relevance for the determination of the prognosis of patients.

\section{Acknowledgments}

We thank Melanie Nurtsch (University Medical Center Erlangen) for excellent technical assistance, Georg Kochs 
(University of Freiburg) for MxA expression plasmid and MxA antibody, Elisabeth Kremmer (Helmholtz Center Munich) for GBP-1 antibody, and Kerstin Förster-Poller (University Medical Center Erlangen) for preparing the monocytes and T cells. This work is part of a doctoral thesis (S.G.).

S.G., E.N., and M.S. designed experiments; S.G., U.S., and A.K. performed experiments; S.G., E.N., N.B.-L., S.M., T.T.R., and M.S. analyzed data; M.A., A.H., R.S.C., and W.H. provided reagents; and S.G., E.N., and M.S. wrote the manuscript. The final manuscript was approved by all authors.

\section{Supplemental Data}

Supplemental material for this article can be found at http://dx.doi.org/10.1016/j.ajpath.2013.08.025.

\section{References}

1. Ferlay J, Shin HR, Bray F, Forman D, Mathers C, Parkin DM: Estimates of worldwide burden of cancer in 2008: GLOBOCAN 2008. Int J Cancer 2010, 127:2893-2917

2. Weitz J, Koch M, Debus J, Hohler T, Galle PR, Buchler MW: Colorectal cancer. Lancet 2005, 365:153-165

3. Lynch HT, de la Chapelle A: Hereditary colorectal cancer. N Engl J Med 2003, 348:919-932

4. Hanahan D, Weinberg RA: Hallmarks of cancer: the next generation. Cell 2011, 144:646-674

5. Folkman J: Angiogenesis. Annu Rev Med 2006, 57:1-18

6. Krok KL, Lichtenstein GR: Colorectal cancer in inflammatory bowel disease. Curr Opin Gastroenterol 2004, 20:43-48

7. Philip M, Rowley DA, Schreiber H: Inflammation as a tumor promoter in cancer induction. Semin Cancer Biol 2004, 14:433-439

8. Kaiko GE, Horvat JC, Beagley KW, Hansbro PM: Immunological decision-making: how does the immune system decide to mount a helper T-cell response? Immunology 2008, 123:326-338

9. Galon J, Costes A, Sanchez-Cabo F, Kirilovsky A, Mlecnik B, LagorcePages C, Tosolini M, Camus M, Berger A, Wind P, Zinzindohoue F, Bruneval P, Cugnenc PH, Trajanoski Z, Fridman WH, Pages F: Type, density, and location of immune cells within human colorectal tumors predict clinical outcome. Science 2006, 313:1960-1964

10. Camus M, Tosolini M, Mlecnik B, Pages F, Kirilovsky A, Berger A, Costes A, Bindea G, Charoentong P, Bruneval P, Trajanoski Z, Fridman WH, Galon J: Coordination of intratumoral immune reaction and human colorectal cancer recurrence. Cancer Res 2009, 69: $2685-2693$

11. Naschberger E, Croner RS, Merkel S, Dimmler A, Tripal P, Amann KU, Kremmer E, Brueckl WM, Papadopoulos T, Hohenadl C, Hohenberger W, Stürzl M: Angiostatic immune reaction in colorectal carcinoma: impact on survival and perspectives for antiangiogenic therapy. Int J Cancer 2008, 123:2120-2129

12. Dunn GP, Koebel CM, Schreiber RD: Interferons, immunity and cancer immunoediting. Nat Rev Immunol 2006, 6:836-848

13. Boehm U, Klamp T, Groot M, Howard JC: Cellular responses to interferon-gamma. Annu Rev Immunol 1997, 15:749-795

14. Stark GR, Kerr IM, Williams BR, Silverman RH, Schreiber RD: How cells respond to interferons. Annu Rev Biochem 1998, 67: 227-264

15. Dunn GP, Bruce AT, Ikeda H, Old LJ, Schreiber RD: Cancer immunoediting: from immunosurveillance to tumor escape. Nat Immunol 2002, 3:991-998
16. Ikeda H, Old LJ, Schreiber RD: The roles of IFN gamma in protection against tumor development and cancer immunoediting. Cytokine Growth Factor Rev 2002, 13:95-109

17. Guenzi E, Töpolt K, Cornali E, Lubeseder-Martellato C, Jörg A, Matzen K, Zietz C, Kremmer E, Nappi F, Schwemmle M, Hohenadl C, Barillari G, Tschachler E, Monini P, Ensoli B, Stürzl M: The helical domain of GBP-1 mediates the inhibition of endothelial cell proliferation by inflammatory cytokines. EMBO J 2001, 20: $5568-5577$

18. Hervas-Stubbs S, Perez-Gracia JL, Rouzaut A, Sanmamed MF, Le Bon A, Melero I: Direct effects of type I interferons on cells of the immune system. Clin Cancer Res 2011, 17:2619-2627

19. Diamond MS, Kinder M, Matsushita H, Mashayekhi M, Dunn GP, Archambault JM, Lee H, Arthur CD, White JM, Kalinke U, Murphy KM, Schreiber RD: Type I interferon is selectively required by dendritic cells for immune rejection of tumors. J Exp Med 2011, 208:1989-2003

20. Singh RK, Gutman M, Bucana CD, Sanchez R, Llansa N, Fidler IJ Interferons alpha and beta down-regulate the expression of basic fibroblast growth factor in human carcinomas. Proc Natl Acad Sci U S A 1995, 92:4562-4566

21. Dinney CP, Bielenberg DR, Perrotte P, Reich R, Eve BY, Bucana CD, Fidler IJ: Inhibition of basic fibroblast growth factor expression, angiogenesis, and growth of human bladder carcinoma in mice by systemic interferon-alpha administration. Cancer Res 1998, 58:808-814

22. Belardelli F, Ferrantini M, Proietti E, Kirkwood JM: Interferon-alpha in tumor immunity and immunotherapy. Cytokine Growth Factor Rev 2002, 13:119-134

23. Ferrantini M, Capone I, Belardelli F: Interferon-alpha and cancer: mechanisms of action and new perspectives of clinical use. Biochimie 2007, 89:884-893

24. Dunn GP, Bruce AT, Sheehan KC, Shankaran V, Uppaluri R, Bui JD, Diamond MS, Koebel CM, Arthur C, White JM, Schreiber RD: A critical function for type I interferons in cancer immunoediting. Nat Immunol 2005, 6:722-729

25. Seok J, Warren HS, Cuenca AG, Mindrinos MN, Baker HV, Xu W, et al: Genomic responses in mouse models poorly mimic human inflammatory diseases. Proc Natl Acad Sci U S A 2013, 110: $3507-3512$

26. Aebi M, Fah J, Hurt N, Samuel CE, Thomis D, Bazzigher L, Pavlovic J, Haller O, Staeheli P: cDNA structures and regulation of two interferon-induced human Mx proteins. Mol Cell Biol 1989, 9: $5062-5072$

27. Goetschy JF, Zeller H, Content J, Horisberger MA: Regulation of the interferon-inducible IFI-78K gene, the human equivalent of the murine Mx gene, by interferons, double-stranded RNA, certain cytokines, and viruses. J Virol 1989, 63:2616-2622

28. Indraccolo $\mathrm{S}$, Pfeffer $\mathrm{U}$, Minuzzo $\mathrm{S}$, Esposito $\mathrm{G}$, Roni $\mathrm{V}$, Mandruzzato S, Ferrari N, Anfosso L, Dell'Eva R, Noonan DM, ChiecoBianchi L, Albini A, Amadori A: Identification of genes selectively regulated by IFNs in endothelial cells. J Immunol 2007, 178:1122-1135

29. al-Masri AN, Werfel T, Jakschies D, von Wussow P: Intracellular staining of Mx proteins in cells from peripheral blood, bone marrow and skin. Mol Pathol 1997, 50:9-14

30. Abrams ME, Balish MJ, Brandt CR: IFN-alpha induces MxA gene expression in cultured human corneal fibroblasts. Exp Eye Res 1995, 60:137-142

31. Mushinski JF, Nguyen P, Stevens LM, Khanna C, Lee S, Chung EJ, Lee MJ, Kim YS, Linehan WM, Horisberger MA, Trepel JB: Inhibition of tumor cell motility by the interferon-inducible GTPase MxA. J Biol Chem 2009, 284:15206-15214

32. Cheng YS, Colonno RJ, Yin FH: Interferon induction of fibroblast proteins with guanylate binding activity. J Biol Chem 1983, 258: $7746-7750$

33. Lubeseder-Martellato C, Guenzi E, Jörg A, Töpolt K, Naschberger E, Kremmer E, Zietz C, Tschachler E, Hutzler P, Schwemmle M, 
Matzen K, Grimm T, Ensoli B, Stürzl M: Guanylate-binding protein1 expression is selectively induced by inflammatory cytokines and is an activation marker of endothelial cells during inflammatory diseases. Am J Pathol 2002, 161:1749-1759

34. Ammon C, Meyer SP, Schwarzfischer L, Krause SW, Andreesen R, Kreutz M: Comparative analysis of integrin expression on monocytederived macrophages and monocyte-derived dendritic cells. Immunology 2000, 100:364-369

35. Gary R, Voelk1 S, Palmisano R, Ullrich E, Bosch JJ, Mackensen A: Antigen-specific transfer of functional programmed death ligand 1 from human APCs onto CD8 + T cells via trogocytosis. J Immunol 2012, 188:744-752

36. Sobin LH, Gospodarowicz MK, Wittekind C, (Eds): International Union Against Cancer (UICC): TNM Classification of Malignant Tumors. ed 7. Oxford, Wiley-Blackwell, 2009

37. Jass JR, Sobin LH, (Eds): Histological Classification of Tumors. Berlin, Springer, 1989

38. Soreide O, Norstein J, Fielding LP, Silen W, (Eds): International Standardization and Documentation of the Treatment of Rectal Cancer. Berlin, Springer, 1997

39. Meyer T, Merkel S, Reingruber B, Papadopoulos T, Wein A, Hahn E, Hohenberger W: The benefit of adjuvant chemotherapy in colorectal carcinoma UICC stage III depends on surgical quality: results of the intact I trial. Onkologie 2008, 31(Suppl 1):80-81

40. Kuhn E, Naschberger E, Konrad A, Croner RS, Britzen-Laurent N, Jochmann R, Munstedt H, Stürzl M: A novel chip-based parallel transfection assay to evaluate paracrine cell interactions. Lab Chip 2012, 12:1363-1372

41. Stertz S, Reichelt M, Krijnse-Locker J, Mackenzie J, Simpson JC, Haller O, Kochs G: Interferon-induced, antiviral human MxA protein localizes to a distinct subcompartment of the smooth endoplasmic reticulum. J Interferon Cytokine Res 2006, 26:650-660

42. Flohr F, Schneider-Schaulies S, Haller O, Kochs G: The central interactive region of human MxA GTPase is involved in GTPase activation and interaction with viral target structures. FEBS Lett 1999, 463:24-28

43. Stürzl M, Hohenadl C, Zietz C, Castanos-Velez E, Wunderlich A, Ascherl G, Biberfeld P, Monini P, Browning PJ, Ensoli B: Expression of K13/v-FLIP gene of human herpesvirus 8 and apoptosis in Kaposi's sarcoma spindle cells. J Natl Cancer Inst 1999, 91: $1725-1733$

44. Stürzl M, Roth WK, Brockmeyer NH, Zietz C, Speiser B, Hofschneider PH: Expression of platelet-derived growth factor and its receptor in AIDS-related Kaposi sarcoma in vivo suggests paracrine and autocrine mechanisms of tumor maintenance. Proc Natl Acad Sci U S A 1992, 89:7046-7050

45. Tripal P, Bauer M, Naschberger E, Mörtinger T, Hohenadl C, Cornali E, Thurau M, Stürzl M: Unique features of different members of the human guanylate-binding protein family. J Interferon Cytokine Res 2007, 27:44-52

46. Greenwood M: The natural duration of cancer. Rep Publ Hlth Med Subj 1926, 33:1-26

47. Britzen-Laurent N, Lipnik K, Ocker M, Naschberger E, Schellerer VS, Croner RS, Vieth M, Waldner M, Steinberg P, Hohenadl C, Stürzl M: GBP-1 acts as a tumor suppressor in colorectal cancer cells. Carcinogenesis 2013, 34:153-162
48. Naschberger E, Werner T, Vicente AB, Guenzi E, Töpolt K, Leubert R, Lubeseder-Martellato C, Nelson PJ, Stürzl M: Nuclear factor-kappaB motif and interferon-alpha-stimulated response element co-operate in the activation of guanylate-binding protein-1 expression by inflammatory cytokines in endothelial cells. Biochem J 2004, 379:409-420

49. Foster GR, Masri SH, David R, Jones M, Datta A, Lombardi G, Runkell L, de Dios C, Sizing I, James MJ, Marelli-Berg FM: IFNalpha subtypes differentially affect human T cell motility. J Immunol 2004, 173:1663-1670

50. Sayers TJ, Wiltrout TA, McCormick K, Husted C, Wiltrout RH: Antitumor effects of alpha-interferon and gamma-interferon on a murine renal cancer (Renca) in vitro and in vivo. Cancer Res 1990, 50:5414-5420

51. Abadie A, Besancon F, Wietzerbin J: Type I interferon and TNFalpha cooperate with type II interferon for TRAIL induction and triggering of apoptosis in SK-N-MC EWING tumor cells. Oncogene 2004, 23: 4911-4920

52. Parronchi P, De Carli M, Manetti R, Simonelli C, Sampognaro S, Piccinni MP, Macchia D, Maggi E, Del Prete G, Romagnani S: IL-4 and IFN (alpha and gamma) exert opposite regulatory effects on the development of cytolytic potential by Th1 or Th2 human $\mathrm{T}$ cell clones. J Immunol 1992, 149:2977-2983

53. Brinkmann V, Geiger $\mathrm{T}$, Alkan $\mathrm{S}$, Heusser $\mathrm{CH}$ : Interferon alpha increases the frequency of interferon gamma-producing human CD4+ T cells. J Exp Med 1993, 178:1655-1663

54. Hunter CA, Gabriel KE, Radzanowski T, Neyer LE, Remington JS: Type I interferons enhance production of IFN-gamma by NK cells. Immunol Lett 1997, 59:1-5

55. Rogge L, D'Ambrosio D, Biffi M, Penna G, Minetti LJ, Presky DH, Adorini L, Sinigaglia F: The role of Stat 4 in species-specific regulation of Th cell development by type I IFNs. J Immunol 1998, 161:6567-6574

56. Cousens LP, Peterson R, Hsu S, Dorner A, Altman JD, Ahmed R, Biron CA: Two roads diverged: interferon alpha/beta- and interleukin 12-mediated pathways in promoting $\mathrm{T}$ cell interferon gamma responses during viral infection. J Exp Med 1999, 189:1315-1328

57. McRae BL, Semnani RT, Hayes MP, van Seventer GA: Type I IFNs inhibit human dendritic cell IL-12 production and Th1 cell development. J Immunol 1998, 160:4298-4304

58. Byrnes AA, Ma X, Cuomo P, Park K, Wahl L, Wolf SF, Zhou H, Trinchieri G, Karp CL: Type I interferons and IL-12: convergence and cross-regulation among mediators of cellular immunity. Eur J Immunol 2001, 31:2026-2034

59. Nguyen KB, Cousens LP, Doughty LA, Pien GC, Durbin JE, Biron CA: Interferon alpha/beta-mediated inhibition and promotion of interferon gamma: STAT1 resolves a paradox. Nat Immunol 2000, $1: 70-76$

60. Nguyen KB, Watford WT, Salomon R, Hofmann SR, Pien GC, Morinobu A, Gadina M, O'Shea JJ, Biron CA: Critical role for STAT4 activation by type 1 interferons in the interferongamma response to viral infection. Science 2002, 297: 2063-2066

61. de Paus RA, van Wengen A, Schmidt I, Visser M, Verdegaal EM, van Dissel JT, van de Vosse E: Inhibition of the type I immune responses of human monocytes by IFN-alpha and IFN-beta. Cytokine 2013, 61:645-655 